\title{
A micronucleus assay detects genotoxic effects of herbicide exposure in a protected butterfly species
}

\author{
Alfredo Santovito $\mathbb{D}^{1} \cdot$ Michela Audisio $^{1} \cdot$ Simona Bonelli $\mathbb{D}^{1}$
}

Accepted: 20 August 2020 / Published online: 3 September 2020

(c) The Author(s) 2020

\begin{abstract}
Lycaena dispar Hawort (Lepidoptera: Lycaenidae), a protected butterfly, is declining in Europe, but it thrives in rice fields in northern Italy. Here, agrochemical usage could threaten its long-term survival. We investigated, by micronucleus (MN) assay, the genotoxic effect of glyphosate, a common herbicide, on $L$. dispar larvae. Micronuclei (MNi) are DNA fragments separated from the main nucleus and represent the result of genomic damage that has been transmitted to daughter cells. In a control/treatment experiment, we extracted epithelial cells from last-instar larvae fed with Rumex spp. plants sprayed with a solution containing $3.6 \mathrm{~g} / \mathrm{L}$ of glyphosate, and from larvae fed with unsprayed plants. MNi and other chromosomal aberrations_-nuclear buds (NBUDs) and bi-nucleated cells_-were then scored in 1000 cells/subject. Significant differences were found between glyphosate-exposed and control groups in terms of $\mathrm{MNi}$ and total genomic damage, but not in terms of NBUDs or bi-nucleated cells. We reported a possible genomic damage induced by glyphosate on larvae of $L$. dispar. For the first time, a MN assay was used in order to evaluate the genomic damage on a phytophagous invertebrate at the larval stage. Increased levels of MNi reflect a condition of genomic instability that can result in reduced vitality and in an increased risk of local extinction. Therefore, farmland management compatible with wildlife conservation is needed.
\end{abstract}

Keywords Pesticides $\cdot$ Roundup $\cdot$ Genomic damage $\cdot$ Lepidoptera $\cdot$ Habitats directive

Legend

Aneugenic damage Damage caused by a substance (aneugen) that causes a daughter cell to have an abnormal number of chromosomes.

Aneuploid cells Cells with an abnormal number of chromosomes, typically with 1 or more missing or excess chromosomes.

Binucleated cells Cells with two nuclei instead of one. The significance of these cells is unknown but they may be indicative of failed cytodieresis following the nuclear division.

Cytodieresis The division of the cytoplasm of a cell following the division of the nucleus.

Clastogenic damage
EEC

ISPRA

Karyolytic cells

MN

MNi

NBUDs

PPP
European Economic Community. Istituto Superiore per la Protezione e la Ricerca Ambientale, Italian name of the Italian Institute for Environmental Protection and Research.

Cells with a nucleus completely depleted of DNA and that apparent as a ghost-like image. These cells thus appear to have no nucleus. They represent a very late stage in the cell death process.

Micronucleus. It represents a chromosome fragment or whole chromosomes that fails to segregate properly during cell division cycle, appearing in interphase as small additional nuclei.

Micronuclei. Plural of Micronucleus. Nuclear buds. They represent the physical manifestation of the elimination process of excess amplified DNA. Plant-protection products.
Simona Bonelli

simona.bonelli@unito.it

1 Department of Life Sciences and Systems Biology, University of Turin, Via Accademia Albertina 13, 10123 Torino, Italy 


\section{Introduction}

In the last decades, the expansion of intensive agriculture has triggered serious ecological problems, in terms of loss of habitats and biodiversity. This is principally due to the excessive use of pesticides, which control populations of targeted pests, but also reduce the fitness of non-target species (Siroski et al. 2016). Pesticides directly and indirectly affect wildlife (Isenring 2010). The use of insecticides and herbicides, for instance, was found to negatively impact butterfly abundance and species richness (for a review see Braak et al. 2018). Indeed, herbicide treatments lead to a reduction of native plants and the insect communities they support; in some cases, this results in a reduction in population size and a higher risk of extinction (Thogmartin et al. 2017; Stenoien et al. 2018). Many studies ascribe the decline of animal populations to agrochemical treatments, for example, birds (Mineau and Whiteside 2013; Donald et al. 2001), reptiles (Mingo et al. 2016; Wagner et al. 2015), amphibians (Brühl et al. 2013; Wagner et al. 2014), and bats (Stahlschmidt and Brühl 2012). Recently, the EU Pollinators Initiative named pesticide use as one of the main causes of the loss of managed bee colonies and the decline of wild bees and other insect pollinators (EU 2019). Although the drivers of this phenomenon are not well understood, there is increasing evidence of negative effects of pesticides on wild and managed bees (Sánchez-Bayo et al. 2016), bumblebees (Stanley et al. 2016) and butterflies (Forister et al. 2016).

In Europe, the mosaic of habitats resulting from traditional farm management has favored a high diversity of flora and fauna (Bignal and McCracken 2000). Agroecosystems host more than half of the 29 European protected butterfly species (van Swaay et al. 2012), and are crucial for threatened butterflies and wild bees (van Swaay et al. 2010; Nieto et al. 2014). Pesticide treatments and other activities connected to agricultural intensification can be a threat to these vulnerable species. For example, pesticides have been reported as one of the causes of the steady decline of some butterflies listed in the Habitats Directive 92/43/EEC (1992) by the European Economic Community (EEC) observed from 1960 (van Swaay et al. 2012). In Italy, 92\% of protected habitats and $56 \%$ of protected animal species are vulnerable to pesticides. Of these, wetlands and their species are the most sensitive (ISPRA 2015). Artificial water surfaces, such as rice fields, can act as surrogate habitats for wetland species (Fasola and Ruiz 1996; Bambaradeniya et al. 2004; Giuliano and Bogliani 2018).

In the 1900s, Lycaena dispar Hawort (Lepidoptera: Lycaenidae), a butterfly listed in the Annexes II-IV of the Directive 92/43/EEC (1992), has disappeared from many natural and semi-natural wetlands (Pullin et al. 1995;
Balletto et al. 2005). At the same time, in the River Po region of northern Italy, $L$. dispar has adapted to live in rice fields, and has actually increased in number as a result of rice cultivation (Balletto et al. 2005; Bonelli et al. 2011). Vegetated rice fields banks are, in fact, where the butterfly finds larval food plants (belonging to the genus Rumex) and nectar sources. In rice crops, field banks are usually intensively managed, to remove weeds with chemical or mechanical procedures (Cardarelli and Bogliani 2014). Intensive management practices, such as the use of nonselective herbicides, have turned the rice field in an 'ecological trap', which has led to a rapid population decline of L. dispar in the second half of the 1900s. (Balletto et al. 2005; Bonelli et al. 2018). In particular, it has been demonstrated that glyphosate spraying, by directly removing food sources, drastically reduces the presence of $L$. dispar (Giuliano et al. 2018). Moreover, we hypothesize that chronic exposure to herbicides can determine sublethal effects that may, in the long term, reduce the fitness and have evolutionary implications. In Italy, rice fields are mainly located in Piedmont, and here the mean annual sales of glyphosate accounted for 3915 tons from 2009 to 2012 (ISPRA 2017).

Glyphosate (N-phosphonomethyl glycine) is a widely used, systemic non-selective herbicide (Costa et al. 2014; Tarazona et al. 2017). Despite its reputation of being safe, glyphosate can contaminate soil and water, leading to cascading effects on non-target organisms (Helander et al. 2012). Toxic effects of glyphosate have been reported for a wide range of organisms (Gill et al. 2018); for example, it was found to cause behavioral and physiological alterations in vertebrate (Avigliano et al. 2014; Navarro-Martín et al. 2014; Uren Webster et al. 2014; Hansen and Roslev 2016) and invertebrate species (Schneider et al. 2009; Balbuena et al. 2015; Xu et al. 2017; Blot et al. 2019). We also have evidence of genotoxicity of this chemical; for instance, in human lymphocytes it was found to increase the frequency of micronuclei (MNi) (Santovito et al. 2018), whereas other forms of DNA damage have been described in different cell types (Monroy et al. 2005; Mañas et al. 2009; Koller et al. 2012). However, commercial pesticide products comprise the active substance with adjuvants or surfactants. Although these last are considered inert ingredients, in many cases their toxicity exceeds or intensifies the toxicity of the active ingredient (Beggel et al. 2010; Cox and Surgan 2006; Beggel et al. 2010). For these reasons, recently, the cytotoxic and genotoxic effects were also evaluated on glyphosate-based herbicides, such as Roundup ${ }^{\circledast}$. Roundup ${ }^{\circledast}$ has been found able to cause genomic damage to human peripheral blood mononuclear cells at a concentration of $5 \mu \mathrm{M}$, a value lower than that observed for glyphosate, which was found to induce DNA lesions starting from a 
concentration of $500 \mu \mathrm{M}$ (Woźniak et al. 2018). The genotoxic effect of glyphosate-based herbicides has already been tested with MN assay on some vertebrate taxa, such as fish (Grisolia 2002; Cavalcante et al. 2008), reptiles (Poletta et al. 2009; Schaumburg et al. 2016), and amphibians (Bosch et al. 2011). On the other hand, nobody tested the response of phytophagous terrestrial invertebrates, although they can be exposed to this herbicide through their diet.

To reduce pesticide risk and impact on human health, as well as the environment and biodiversity, is an issue of major concern in the European union (Council Directive 2009/128/EC 2009). For this reason, to decrease the overall use of chemical pesticides is one of the aims of the EU Biodiversity Strategy for 2030 (EC 2020a). Protecting the environment is also a goal of the Regulation (EC) 1107/ 2009 (2009) for plant-protection-products (PPP) authorization. In order to authorize a new PPP, standard toxicity tests are required using specific test subjects. However, an open challenge is to develop a risk assessment scheme to specifically address indirect impacts of pesticides on different organisms, since no guidelines are presently available (Streloke 2011). Specifically, to better understand the impacts of agrochemicals, more ecotoxicological data are required to assess sublethal effects of a chemical on nontarget species, as well as those of conservation concern. There is very little evidence about the impact of agrochemicals on protected species; for example, the bioaccumulation of organoclorurate pesticides in the Eurasian otter (Lutra lutra Linnaeus) (Lemarchand et al. 2010). In fact, nowadays laboratory toxicity tests use a limited number of test species and only examine lethal effects over short time frames, while ecologically relevant sublethal effects are less frequently described. Many of the tests use insensitive species and are not sufficiently long to represent chronic exposure and, therefore, lack environmental relevance.

In the light of what have been said, the aim of the present work was to investigate- by micronucleus (MN) assaythe genotoxic effect of the glyphosate-based herbicide Roundup on larvae of $L$. dispar. MNi represent chromosome fragments or whole chromosomes that fail to segregate properly during mitosis, appearing in interphase as small additional nuclei. They are the result of clastogenic or aneugenic damage that has been transmitted to daughter cells. Chromosomal instability was also measured by scoring both NBUDs, which represent the elimination process of amplified DNA and/or excess chromosomes from aneuploid cells, and bi-nucleated cells, that are the result of impairment of cytodieresis (Fenech et al. 2011). The tested hypothesis was to evaluate if Roundup ${ }^{\circledR}$ affects $L$. dispar in terms of genomic damage induction at the larval stage, with consequent reduction in larvae vitality and with important evolutionary implications.

\section{Materials and methods}

\section{Larval rearing experiment and exposure to glyphosate}

Rumex leaves with $L$. dispar eggs were collected in a rice field in Rovasenda (Vercelli, Piedmont), 45 $33^{\prime} 01^{\prime \prime} \mathrm{N}, 8^{\circ} 19^{\prime}$ $25^{\prime \prime} \mathrm{E}$, at the beginning of September 2019. We decided to collect the eggs in a place where they would have ended up in a 'ecological trap' due to management practices, so we selected a field margin that was going to be moved in a few days, compromising the survival of the larvae. The sampling of the eggs of this protected species was authorized by the Italian Ministry of the Environment, Land and Sea, by derogation from Article 16 of the Directive 92/43/EEC (1992) (protocol number 26142). Eggs were then brought to the laboratory to be raised. A total of 85 eggs were collected, and then placed in Petri dishes in groups of ten. Fresh Rumex leaves were added every day for the newlyhatched larvae. At day 1 after hatching, the young larvae were divided in two groups; one group was placed on a Rumex plant sprayed with $1 \%$ Roundup ${ }^{\circledast}$ Power 2.0 containing $3.6 \mathrm{~g} / \mathrm{L}$ of glyphosate, which represents a dose commonly used in agricultural practices (glyphosateexposed group), and the other on an unsprayed Rumex plant (control group). Plants and larvae were kept in two separated net-cages in a climate cell at $26^{\circ} \mathrm{C}$ L:D 15:9 (typical environmental conditions in their natural habitat during summer) and the plants were watered every 2-3 days. Sprayed plants withered after 8-9 days so they were replaced with new fresh plants, and sprayed with the herbicide, in order to provide larvae with food.

\section{Micronucleus assay}

The larvae reached the last instar after 15-18 days, and were then dissected; their cuticle was cut using a micro-scissor and the hemolymph was collected by rubbing on a slide, while the epithelial cells were collected using a spatula. The tip of the spatula was directly dipped into a tube containing a fixative solution of 3:1 methanol/acetic acid and stored at $4{ }^{\circ} \mathrm{C}$ prior to analysis. Successively, cells were collected by centrifugation, supernatants were discarded and the pellets, dissolved in a minimal volume of fixative, were seeded onto slides to detect $\mathrm{MNi}$ by conventional staining with $5 \%$ Giemsa (pH 6.8) prepared in Sörensen buffer. Microscopic analysis was performed at $\times 400$ magnification on a light microscope, whereas checking and photos of micronucleated cells were performed at $\times 1000$ magnification. $\mathrm{MNi}, \mathrm{NBUDs}$, binucleated and karyolitic cells were scored in 1000 cells per subject, following the established criteria for MNi evaluation (Thomas et al. 2009). 
Fig. 1 Examples of haemocytes stained with $5 \%$ Giemsa observed in both control and glyphosate-exposed samples. a Haemocytes observed at $\times 160$ magnification. b, c Haemocytes observed at $\times 400$ and $\times 1000$ magnification, respectively

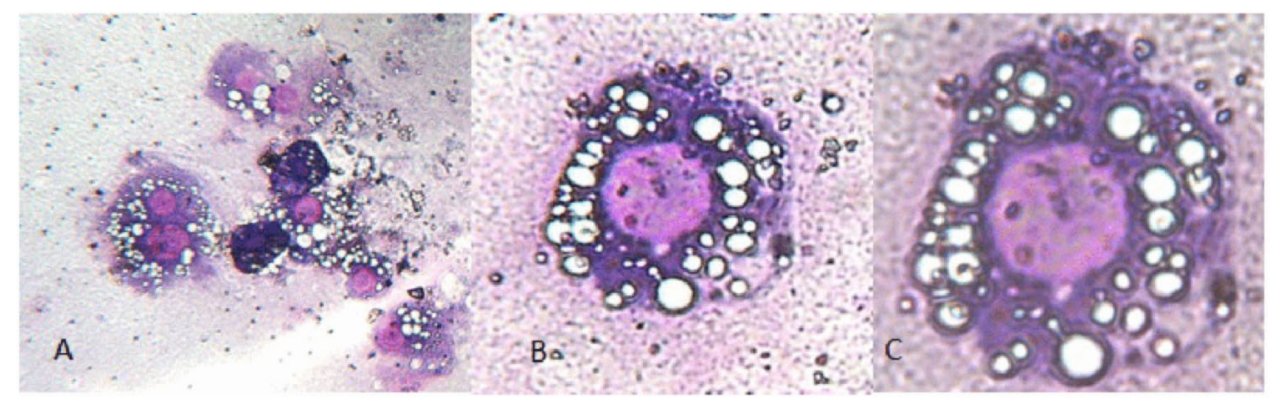

Table 1 Results of the statistical evaluation of genomic damage between glyphosate-exposed and control groups. Only significant results were reported

\begin{tabular}{lcccccc}
\hline & $N$ & Cells & MNi (mean \pm SD\%) & $\begin{array}{l}\text { NBUDs } \\
(\text { mean } \pm \text { SD } \%)\end{array}$ & $\begin{array}{l}\text { Bi-nucleated cells } \\
(\text { mean } \pm \text { SD })\end{array}$ & $\begin{array}{l}\text { Total genomic damage } \\
(\mathrm{mean} \pm \text { SD })\end{array}$ \\
\hline Controls & 19 & 16,585 & $26(0.137 \pm 0.164)$ & $9(0.066 \pm 0.121)$ & $24(0.126 \pm 0.148)$ & $35(0.203 \pm 0,171)$ \\
Glyphosate-exposed & 26 & 23,757 & $102(0.442 \pm 0.337)^{*}$ & $27(0.117 \pm 0.127)$ & $44(0.204 \pm 0.328)$ & $129(0.560 \pm 0.420)^{* *}$ \\
\hline
\end{tabular}

Only significant results were reported

$M N i$ micronuclei, $N B U D$ s nuclear buds, $S D$ standard deviation

$* P=0.002 ; * * P=0.001$, compared to the controls (Kruskal-Wallis test)

\section{Statistical analysis}

Statistical analyses were conducted using the SPSS software statistical package program (version 25.0, IBM Corp 2017). Differences between glyphosate-exposed and controls were evaluated by Kruskal-Wallis non-parametric test. All $P$ values were two-tailed and the level of statistical significance was set at $P<0.05$ for all tests.

\section{Results}

We obtained 64 larvae from the eggs that we collected, which were divided into 32 glyphosate-exposed and 32 control subjects. Development time of the larvae was comparable between the two groups (about two weeks). A sample of 6 glyphosate-exposed larvae and 13 control individuals was randomly chosen and allowed to pupate, and they reached the adult stage without any visible morphological anomalies.

Finally, a MN assay was performed on 26 glyphosateexposed larvae and 19 control subjects. Although only about 200 cells were scored for six subjects (three controls and three glyphosate-exposed larvae), we decided to include them in the analyzed sample. A total of 16,585 and 23,757 cells were analyzed for control and glyphosate-exposed larvae, respectively. In Fig. 1, some examples of observed haemocytes in both control and exposed larvae are reported. Unfortunately, it was not possible to apply the MN assay to haemocytes due to their intense cytoplasmic vacuolization, which interferes with the observation of MNi and NBDUs. In Table 1, the frequencies of $\mathrm{MNi}$, NBUDs and binucleated cells in both glyphosate-exposed and control groups are reported. In Fig. 2, some examples of the observed damaged cells are shown. In the control group, the frequency of $\mathrm{MNi}$, NBUDs and bi-nucleated cells were $0.137 \pm 0.164,0.066 \pm 0.121$, and $0.126 \pm 0.148$ respectively, whereas in the glyphosate-exposed group, these frequencies were $0.442 \pm 0.337,0.177 \pm 0.127$ and $0.204 \pm$ 0.328 , respectively. Significant differences were found between glyphosate-exposed and control groups in terms of MNi $(\mathrm{H}=9.974, P=0.002)$ and total genomic damage $(\mathrm{H}=11.996, \quad P=0.001)$, whereas the differences in NBUDs $(\mathrm{H}=3.427, P=0.064)$ and bi-nucleated cells $(\mathrm{H}=0.044, P=0.883)$ frequencies were not significant, although the glyphosate-exposed group showed higher values $(0.117 \pm 0.127$ and $0.204 \pm 0.328$ respectively $)$.

\section{Discussion}

Many authors have pointed out that excessive pesticide usage has a negative effect on wildlife, especially on birds (Donald et al. 2001; Mineau and Whiteside 2013), reptiles (Mingo et al. 2016), amphibians (Brühl et al. 2013), bats (Stebbings and Griffith 1986) and insect pollinators (Forister et al. 2016; Sánchez-Bayo et al. 2016; Stanley et al. 2016).

Glyphosate is the most widely used broad-spectrum herbicide in the world, with known toxicity (Avigliano et al. 
Fig. 2 Examples of micronuclei and nuclear buds observed in the samples, stained with 5\% Giemsa and observed at $\times 400(\mathbf{a}$, b, i) and $\times 1000$ magnification (c $\mathbf{d}, \mathbf{e}, \mathbf{f}, \mathbf{g}, \mathbf{h})$. a-c Cells with micronucleus; $\mathbf{d}-\mathbf{f}$ nuclear buds; g-i bi-nucleated cells

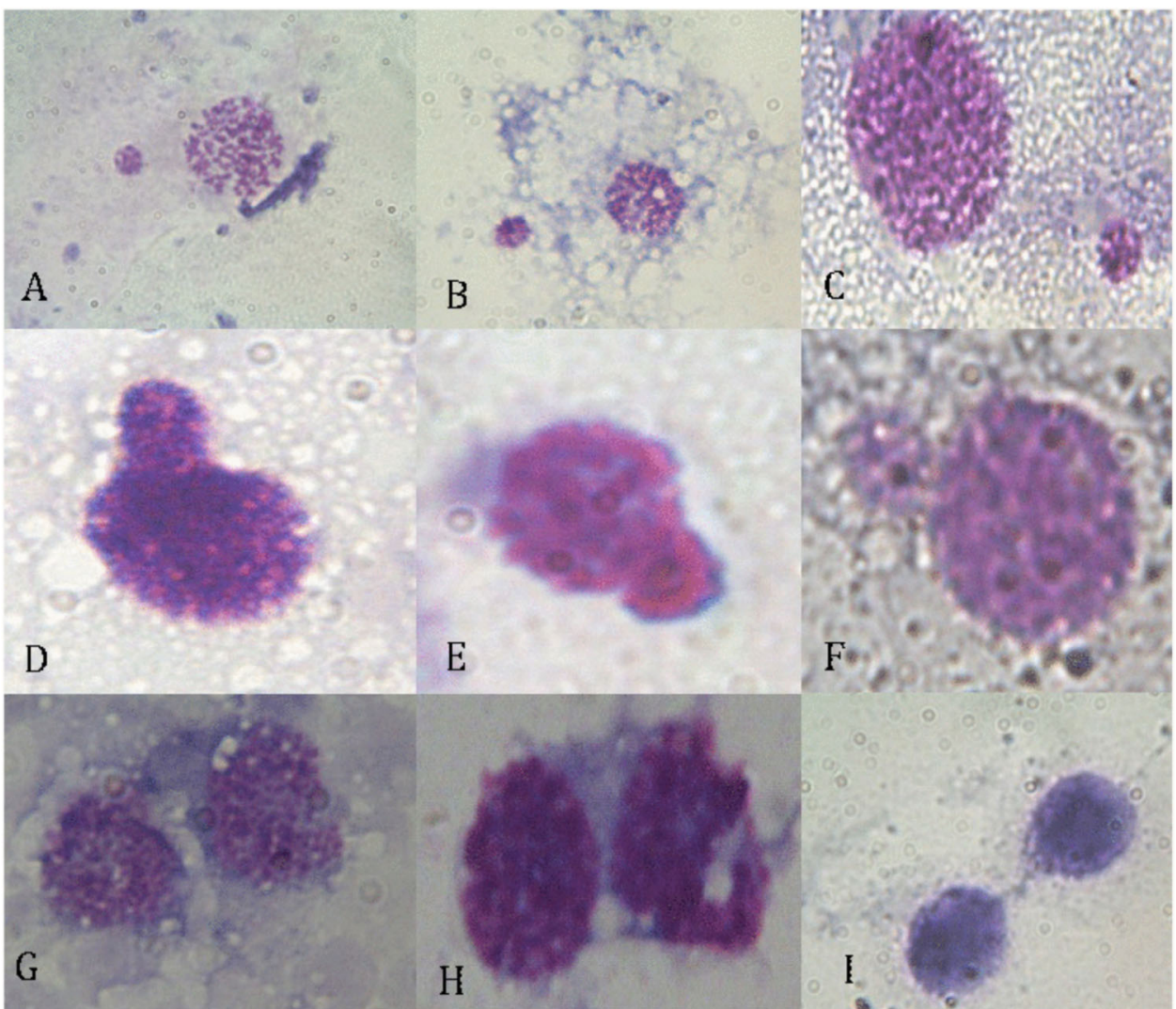

2014; Navarro-Martín et al. 2014; Uren Webster et al. 2014; Zhang et al. 2019). However, glyphosate-based herbicides, as well as all other pesticides, contains inert ingredients that facilitate the access to cells by the active component but that, in some cases, can harm humans and the environment (Giesy et al. 2000; Cox and Surgan 2006). In this sense, new testing methodologies and new ecotoxicological studies on commercial glyphosate-based formulations are needed to provide information about their toxicity to nontarget organisms (van der Sluijs et al. 2015). The toxicity of glyphosate commercial formulations has been well studied across vertebrates, such as fishes, amphibians and reptiles (Navarro-Martín et al. 2014; Uren Webster et al. 2014; Carpenter et al. 2016; Siroski et al. 2016). In this article, we have shown that sublethal exposure to glyphosate-based herbicide Roundup ${ }^{\circledast}$ is able to induce, in $L$. dispar larvae, a significantly increased level of genomic damage, in terms of a higher frequency of MNi.

Sublethal effects of both glyphosate and glyphosatebased herbicides on invertebrates' development have been already documented. For example, bee larvae fed with food containing glyphosate traces $(1.25-5.0 \mathrm{mg}$ per litre of food) were shown to have delayed molting and reduced weight (Vázquez et al. 2018). Similarly, in damselfly larvae, Roundup concentrations from 1.5 to $2 \mathrm{mg} / \mathrm{l}$ were found to reduce growth and to increase the expression levels of the stress protein Hsp70 (Janssens and Stoks 2017). Sublethal doses of pesticides are also well known to impact insect behaviors. For example, sublethal exposure to deltamethrin was found to diminish maternal egg care (Meunier et al. 2020), to impair orientation and memory and to increase stimulus sensitivity, general excitement and disordered movements (Zhang et al. 2020; Decourtye et al. 2004; Ramirez-Romero et al. 2005; Thompson 2003). However, whereas understanding of sublethal effects typically focuses on physiological and behavioral parameters (Mc Luckie et al. 2020; Meunier et al. 2020), in the present work we emphasize the importance of sublethal effects on genome integrity and, more importantly, we revealed for the first time that these effects can be observed also at the larval stage. Indeed, here we report a possible genomic damage induced by Roundup, a common glyphosate-based herbicide applied in a broad diversity of crops worldwide, on larvae of $L$. dispar, a butterfly listed in the Directive 92/43/ EEC (1992). In particular, for the first time, the MN assay was used in order to evaluate the genomic damage on a phytophagous invertebrate at the larval stage. Although MN assay requires the dissection of the studied animal, the positive aspect is that it allows the observation, in a short time and on a non-target organism, of biological effects due to chronic exposure to sublethal doses of an herbicide. Moreover, it should be recalled that these non-lethal effects 
are not commonly assessed in regular exposure impact studies. This work also provides important insights on the diversity of sublethal effects possibly occurring in insects, and confirming the potentiality of the use of non-model organisms to study them.

Increased levels of $\mathrm{MNi}$ reflect a condition of genomic instability that can result in a reduction of vitality and an increased extinction risk. Indeed, $\mathrm{MNi}$ do not only are the product of cytogenetic errors, but, recently, it has been suggested that they represent a mechanism of elimination of genetic material, such as amplified genes, and that they could contribute to nuclear dynamics and genome chaos (Heng 2019; Ye et al. 2019). Genome chaos represents a process of rapid genome re-organization that results in the formation of chaotic genomes, some of which could be selected to establish stable genomes (Ye et al. 2019). Not all MNi can be simply eliminated, but some of them may perform biological functions, such as DNA synthesis, and/ or rejoining into other nuclei, further contributing to abnormal karyotypes or changing the coding genome by integrating new genomic material (Ye et al. 2019). It seems that the stress response is the key evolutionary mechanism in terms of short-term adaptation. Pesticides may act as stressors, and, in this sense, genome chaos could represent an evolutionary mechanism that provides a survival strategy under stress, by means of genomic re-organization. Interestingly, genome chaos has also been hypothesized to represent an effective means for speciation, as it could be responsible for a rapid speciation event during massive extinctions (Heng 2019; Ye et al. 2019). This could be the case of the Italian population of $L$. dispar; in rice fields, agrochemicals and shortage of food sources can act as strong selective pressures. As was demonstrated by Gibbs and Van Dyck (2010) on the butterfly Pararge aegeria Linnaeus, rapid changes in life history traits occur in highly fragmented and low habitat-quality human-modified landscapes. Thus, in this anthropic environment, positive selection for individuals with a higher mobility and with greater fecundity is predicted. However, this is a hypothetical and optimistic scenario, and, actually, for the studied species, we have no evidence of a successful adaptation process. Vice versa, it is more likely that the effects inducing genomic chaos may lead to a decreased average fitness and to an associated increased risk of local extinction.

\section{Conclusions}

In the face of the dramatic disappearance of natural wetlands, rice fields are a perfect example of a surrogate wetland habitat for $L$. dispar, as well as other wetland species (Pullin et al. 1995; Balletto et al. 2005), but pesticides (in particular herbicides) can compromise their long-term survival, not only by change in habitat quality and depletion of food sources but also by genotoxic effects.

In view of these detrimental effects on a European protected species, crop protection strategies compatible with wildlife conservation are needed. In particular, as stated by the Regulation (EC) 1107/2009 (2009), it is desirable to reduce pesticide input and have a correct use of chemicals when and where they are needed. In the case of Roundup, the latter aspect is not entirely negligible, given that very often, in common agricultural practices, it is over-sprayed without precautions for avoiding drift spray (low-drift and low-pressure injectors) and without respecting buffer zones (Cederlund 2017).

Finally, it is necessary to give priority to non-chemical and natural alternatives, for example to promote organic farming; this is actually the aim of the EU Pollinator Initiative and the focus of the debate for the next Common Agricultural Policy reform (EC 2020b).

\section{Data availability}

The authors declare the availability of data and material.

Acknowledgements This work was supported by the University of Turin with local 2015-2018 grants, was carried out in the framework of the National Action Plan (NAP) on the Sustainable Use of Pesticides, founded by the Italian Institute for Environmental Protection and Research (ISPRA), and was authorized (Prot. number 26142) by the Italian Ministry of the Environment, Land and Sea. Open access funding provided by Università degli Studi di Torino within the CRUICARE Agreement.

Funding This work was supported by the University of Turin with local 2015-2018 grants.

Author contributions All authors contributed equally to this work.

\section{Compliance with ethical standards}

Conflict of interest The authors declare that they have no conflict of interest.

Ethical approval The animal used in this article is an insect.

Informed consent All the related authors have known the informed consent.

Publisher's note Springer Nature remains neutral with regard to jurisdictional claims in published maps and institutional affiliations.

Open Access This article is licensed under a Creative Commons Attribution 4.0 International License, which permits use, sharing, adaptation, distribution and reproduction in any medium or format, as long as you give appropriate credit to the original author(s) and the source, provide a link to the Creative Commons license, and indicate if changes were made. The images or other third party material in this article are included in the article's Creative Commons license, unless indicated otherwise in a credit line to the material. If material is not 
included in the article's Creative Commons license and your intended use is not permitted by statutory regulation or exceeds the permitted use, you will need to obtain permission directly from the copyright holder. To view a copy of this license, visit http://creativecommons. org/licenses/by/4.0/.

\section{References}

Avigliano L, Fassiano AV, Medesani DA, de Molina MCR, Rodríguez EM (2014) Effects of glyphosate on growth rate, metabolic rate and energy reserves of early juvenile crayfish, Cherax quadricarinatus. Bull Environ Contam Toxicol 92:631-635. https:// doi.org/10.1007/s00128-014-1240-7

Balbuena MS, Tison L, Hahn ML, Greggers U, Menzel R, Farina WM (2015) Effects of sublethal doses of glyphosate on honeybee navigation. J Exp Biol 218:2799-2805. https://doi.org/10.1242/ jeb.117291

Balletto E, Bonelli S, Cassulo L (2005) Mapping the Italian butterfly diversity for conservation. In: Kühn E, Feldmann R, Thomas JA, Settele $\mathbf{J}$ (eds) Studies on the ecology and conservation of butterflies in Europe, Vol. 1: general concepts and case studies. Pensoft Publishers, Sofia-Moscow, p 71-76

Bambaradeniya CNB, Edirisinghe JP, De Silva DN, Gunatilleke CVS, Ranawana KB, Wijekoon S (2004) Biodiversity associated with an irrigated rice agro-ecosystem in Sri Lanka. Biodivers Conserv 13(9):1715-1753

Beggel S, Werner I, Connon RE, Geist JP (2010) Sublethal toxicity of commercial insecticide formulations and their active ingredients to larval fathead minnow (Pimephales promelas). Sci Total Environ 408:3169-3175. https://doi.org/10.1016/j.scitotenv. 2010.04.004

Bignal EM, McCracken DI (2000) The nature conservation value of European traditional farming systems. Environ Rev 8 (3):149-171. https://doi.org/10.1139/a00-009

Blot N, Veillat L, Rouzé R, Delatte H (2019) Glyphosate, but not its metabolite AMPA, alters the honeybee gut microbiota. PLoS ONE 14(4):e0215466. https://doi.org/10.1371/journal.pone. 0215466

Bonelli S, Cerrato C, Loglisci N, Balletto E (2011) Population extinctions in the Italian diurnal lepidoptera: an analysis of possible causes. J Insect Conserv 15:879-890. https://doi.org/10. 1007/s10841-011-9387-6

Bonelli S, Casacci LP, Barbero F, Cerrato C, Dapporto L, Sbordoni V, Scalercio S, Zilli A, Battistoni A, Teofili C, Rondinini C, Balletto E (2018) The first red list of Italian butterflies. Insect Conserv Divers 11:506-521. https://doi.org/10.1111/icad.12293

Bosch B, Mañas F, Gorla N, Aiassa D (2011) Micronucleus test in post metamorphic Odontophrynus cordobae and Rhinella arenarum (Amphibia: Anura) for environmental monitoring. J Toxicol Environ Health Sci 3(6):154-163. https://doi.org/10.5897/ JTEHS. 9000053

Braak N, Neve R, Jones AK, Gibbs M, Breuker CJ (2018) The effects of insecticides on butterflies-a review. Environ Pollut 242:507-518. https://doi.org/10.1016/j.envpol.2018.06.100

Brühl CA, Schmidt T, Piepe S, Alscher A (2013) Terrestrial pesticide exposure of amphibians: an underestimated cause of global decline? Sci Rep 3:1135. https://doi.org/10.1038/srep01135

IBM Corp (2017) IBM SPSS statistics for Windows, version 25.0. IBM Corp, Armonk, NY

Cardarelli E, Bogliani G (2014) Effects of grass management intensity on ground beetle assemblages in rice field banks. Agr Ecosyst Environ 195:120-126

Carpenter JK, Monks JM, Nelson N (2016) The effect of two glyphosate formulations on a small, diurnal lizard (Oligosoma polychroma). Ecotoxicology 25:548-554. https://doi.org/10. 1007/s10646-016-1613-2

Cavalcante DG, Martinez CB, Sofia SH (2008) Genotoxic effects of Roundup on the fish Prochilodus lineatus. Mutat Res 655:41-6. https://doi.org/10.1016/j.mrgentox.2008.06.010

Cederlund H (2017) Effects of spray drift of glyphosate on nontarget terrestrial plants-a critical review. Environ Toxicol Chem 36 (11):2879-2886. https://doi.org/10.1002/etc.3925

Costa MA, Moscardini VF, da Costa P, Carvalho GA, de Oliveira LR, de Oliveira HN (2014) Sublethal and transgenerational effects of insecticides in developing Trichogramma galloi. (Hymenoptera: Trichogrammatidae). Ecotoxicology 23:1399-1408. https://doi. org/10.1007/s10646-014-1282-y

Council Directive 92/43/EEC of 21 May 1992 on the conservation of natural habitats and of wild fauna and flora (OJ L 206, 22.7.1992, p 7). Available on: https://eur-lex.europa.eu/legal-content/EN/ TXT/?uri=OJ:L:1992:206:TOC. Accessed Apr 2020

Cox C, Surgan M (2006) Unidentified inert ingredients in pesticides: implications for human and environmental health. Environ Health Perspect 114:1803-1806. https://doi.org/10.1289/ehp.9374

Decourtye A, Devillers J, Cluzeau S, Charreton M, Pham-Delègue MH (2004) Effects of imidacloprid and deltamethrin on associative learning in honeybees under semi-field and laboratory conditions. Ecotoxicol Environ Saf 57:410-419. https://doi.org/10.1016/j. ecoenv.2003.08.001

Directive 2009/128/EC of the European Parliament and of the Council of 21 October 2009 establishing a framework for Community action to achieve the sustainable use of pesticides. OJ L 309, 24.11.2009, pp 71-86. Available on: https://eur-lex.europa.eu/legal-content/EN/ ALL/?uri=CELEX\%3A32009L0128. Accessed Apr 2020

Donald PF, Green RE, Heath MF (2001) Agricultural intensification and the collapse of Europe's farmland bird populations. Proc R Soc B 268:25-29. https://doi.org/10.1098/rspb.2000.1325

EC (European Commission) (2020a) Communication from the Commission to the European Parliament, the Council, the European Economic and Social Committee and the Committee of the Regions. EU Biodiversity Strategy for 2030. Bringing nature back into our lives, COM/2020/380 final. European Commission. Brussels. 20 May 2020

EC (2020b) https://ec.europa.eu/info/food-farming-fisheries/keypolicies/common-agricultural-policy/rural-development_en. Accessed Mar 2020

EU (2019) European Parliament resolution of 18 December 2019 on the EU Pollinators Initiative 2019/2803 (RSP). https://ec.europa. eu/environment/nature/conservation/species/pollinators/index_en. htm. Accessed Apr 2020

Fasola M, Ruiz X (1996) The value of rice fields as substitutes for natural wetlands for waterbirds in the Mediterranean region. Colon Waterbirds 19:122-128

Fenech M, Kirsch-Volders M, Natarajan AT, Surralles J, Crott JW, Parry J, Norppa H, Eastmond DA, Tucker JD, Thomas (2011) Molecular mechanisms of micronucleus, nucleoplasmic bridge and nuclear bud formation in mammalian and human cells. Mutagenesis 26:125-132. https://doi.org/10.1093/mutage/geq052

Forister ML, Cousens B, Harrison JG, Anderson K, Thorne JH, Waetjen D, Nice CC, De Parsia M, Hladik ML, Meese R, van Vliet $H$ (2016) Increasing neonicotinoid use and the declining butterfly fauna of lowland California. Biol Lett 12(8):20160475. https://doi.org/10.1098/rsbl.2016.0475

Gibbs M, Van Dyck H (2010) Butterfly flight activity affects reproductive performance and longevity relative to landscape structure. Oecologia 163(2):341-350. https://doi.org/10.1007/s00442-0101613-5

Giesy JP, Dobson S, Solomon KR (2000) Ecotoxicological risk assessment for Roundup ${ }^{\circledR}$ herbicide. Rev Environ Contam Toxicol 35-120. https://doi.org/10.1007/978-1-4612-1156-3_2 
Gill JPK, Sethi N, Mohan A, Datta S, Girdhar M (2018) Glyphosate toxicity for animals. Environ Chem Lett 16(2):401-426. https:// doi.org/10.1007/s10311-017-0689-0

Giuliano D, Bogliani G (2018) The orthopterans of the rice agroecosystem in western Lomellina (Lombardy, Italy). Biodivers Data J 6:e24203. https://doi.org/10.3897/BDJ.6.e24203

Giuliano D, Cardarelli E, Bogliani G (2018) Grass management intensity affects butterfly and orthopteran diversity on rice field banks. Agr Ecosyst Environ 267:147-155

Grisolia CK (2002) A comparison between mouse and fish micronucleus test using cyclophosphamide, mitomycin $\mathrm{C}$ and various pesticides. Mutat Res Genet Toxicol Environ Mutagen 518 (2):145-150. https://doi.org/10.1016/s1383-5718(02)00086-4

Hansen LR, Roslev P (2016) Behavioral responses of juvenile Daphnia magna after exposure to glyphosate and glyphosatecopper complexes. Aquat Toxicol 179:36-43. https://doi.org/10. 1016/j.aquatox.2016.08.010

Helander M, Saloniemi I, Saikkonen K (2012) Glyphosate in northern ecosystems. Trends Plant Sci 17(10):569-574. https://doi.org/10. 1016/j.tplants.2012.05.008

Heng HH (2019) Genome chaos: rethinking genetics, evolution, and molecular medicine. Academic Press Elsevier, Cambridge, MA, USA

Isenring R (2010) Pesticides and the loss of biodiversity. Pesticide Action Network Europe, London. http://www.moraybeedinosa urs.co.uk/neonicotinoid/Pesticides_and_the_loss_of_biodiversity. pdf. Accessed Apr 2020

ISPRA (2015) Valutazione del rischio potenziale dei prodotti fitosanitari nelle Aree Natura 2000. Rapporti, 216/2015, ISPRA

ISPRA (2017) Monitoraggio nazionale dei pesticidi nelle acque. Indicazioni per la scelta delle sostanze. Manuali e Linee guida, $152 / 2017$, ISPRA

Janssens L, Stoks R (2017) Stronger effects of Roundup than its active ingredient glyphosate in damselfly larvae. Acquat Toxicol 193:210-216. https://doi.org/10.1016/j.aquatox.2017.10.028

Koller VJ, Fürhacker M, Nersesyan A, Mišík M, Eisenbauer M, Knasmueller S (2012) Cytotoxic and DNA-damaging properties of glyphosate and Roundup in human-derived buccal epithelial cells. Arch Toxicol 86(5):805-813. https://doi.org/10.1007/ s00204-012-0804-8

Lemarchand C, Rosoux R, Berny P (2010) Organochlorine pesticides, $\mathrm{PCBs}$, heavy metals and anticoagulant rodenticides in tissues of Eurasian otters (Lutra lutra) from upper Loire River catchment (France). Chemosphere 80(10):1120-1124. https://doi.org/10. 1016/j.chemosphere.2010.06.026

Mc Luckie C, Moltschaniwskyj N, Gaston T, Dunstan RH, Crompton M, Butcherine P, Benkendorff K, Taylor MD (2020) Lethal and sub-lethal effects of environmentally relevant levels of imidacloprid pesticide to Eastern School Prawn, Metapenaeus macleayi. Sci Total Environ 742:140449. https://doi.org/10.1016/ j.scitotenv.2020.140449

Mañas F, Peralta L, Raviolo J, Ovando HG, Weyers A, Ugnia L, Cid MG, Larripa I, Gorla N (2009) Genotoxicity of glyphosate assessed by the comet assay and cytogenetic tests. Environ Toxicol Phar 28(1):37-41. https://doi.org/10.1016/j.etap.2009.02.001

Meunier J, Dufour J, Van Meyel S, Rault M, Lécureuil C (2020) Sublethal exposure to deltamethrin impairs maternal egg care in the European earwig Forficula auricularia. Chemosphere 258:127383. https://doi.org/10.1016/j.chemosphere.2020.127383

Mineau P, Whiteside M (2013) Pesticide acute toxicity is a better correlate of U.S. Grassland bird declines than agricultural intensification. PLoS ONE 8(2):e57457. https://doi.org/10.1371/journa 1.pone. 0057457

Mingo V, Lötters S, Wagner N (2016) Risk of pesticide exposure for reptile species in the European Union. Environ Pollut 215:164-169. https://doi.org/10.1016/j.envpol.2016.05.011
Monroy CM, Cortés AC, Sicard DM, Groot de Restrepo H (2005) Cytotoxicity and genotoxicity of human cells exposed in vitro to glyphosate. Biomedica 25(3):335-345. http://www.scielo.org.co/ scielo.php?script $=$ sci_arttext $\&$ pid $=$ S0120-41572005000300009 $\& \operatorname{lng}=$ en\&nrm $=$ iso

Navarro-Martín L, Lanctôt C, Jackman P, Park BJ, Doe K, Pauli BD, Trudeau VL (2014) Effects of glyphosate-based herbicides on survival, development, growth and sex ratios of wood frogs (Lithobates sylvaticus) tadpoles. I: chronic laboratory exposures to VisionMax ${ }^{\circledR}$. Aquat Toxicol 154:278-290. https://doi.org/10. 1016/j.aquatox.2014.05.025

Nieto A, Roberts SPM, Kemp J, Rasmont P, Kuhlmann M, García Criado M, Biesmeijer JC, Bogusch P, Dathe HH, De la Rúa P, De Meulemeester T, Dehon M, Dewulf A, Ortiz-Sánchez FJ, Lhomme P, Pauly A, Potts SG, Praz C, Quaranta M, Radchenko VG, Scheuchl E, Smit J, Straka J, Terzo M, Tomozii B, Window J, Michez D (2014) European Red List of bees. Publication Office of the European Union, Luxembourg

Poletta GL, Larriera A, Kleinsorge E, Mudry MD (2009) Genotoxicity of the herbicide formulation Roundup ${ }^{\circledast}$ (glyphosate) in broad-snouted caiman (Caiman latirostris) evidenced by the Comet assay and the Micronucleus test. Mutat Res Genet Toxicol Environ Mutagen 672 (2):95-102. https://doi.org/10.1016/j.mrgentox.2008.10.007

Pullin AS, McLean IFC, Webb MR (1995) Ecology and conservation of Lycaena dispar: British and European perspectives. In: Pullin AS (eds) Ecology and conservation of butterflies. Florencetype Ltd, Stoodleigh, Devon

Ramirez-Romero R, Chaufaux J, Pham-Delègue MH (2005) Effects of $\mathrm{Cry} 1 \mathrm{Ab}$ protoxin, deltamethrin and imidacloprid on the foraging activity and the learning performances of the honeybee Apis mellifera, a comparative approach. Apidologie 36:601-611. https://doi.org/10.1051/apido:2005039

Regulation (EC) No 1107/2009 of the European Parliament and of the Council of 21 October 2009 concerning the placing of plant protection products on the market and repealing Council Directives - 79/117/EEC and 91/414/EEC. OJL 309, 24.11.2009. Available on: https://eurlex.europa.eu/legalcontent/EN/TXT/uri= celex\%3A32009R1107. Accessed Apr 2020

Sánchez-Bayo F, Goulson D, Pennacchio F, Nazzi F, Goka K, Desneux N (2016) Are bee diseases linked to pesticides? - a brief review. Environ Int 89:7-11. https://doi.org/10.1016/j.envint.2016.01.009

Santovito A, Ruberto S, Gendusa C, Cervella P (2018) In vitro evaluation of genomic damage induced by glyphosate on human lymphocytes. Environ Sci Pollut Res 25(34):34693-34700. https://doi.org/10.1007/s11356-018-3417-9

Schaumburg LG, Siroski PA, Poletta GL, Mudry MD (2016) Genotoxicity induced by Roundup ${ }^{\circledR}$ (Glyphosate) in tegu lizard (Salvator merianae) embryos. Pest Biochem Physiol 130:71-78. https://doi.org/10.1016/j.pestbp.2015.11.009

Schneider MI, Sanchez N, Pineda S, Chi H, Ronco A (2009) Impact of glyphosate on the development, fertility and demography of Chrysoperla externa (Neuroptera: Chrysopidae): ecological approach. Chemosphere 76(10):1451-1455. https://doi.org/10. 1016/j.chemosphere.2009.05.029

Siroski P, Poletta GL, Latorre MA, Merchant ME, Ortega HH, Mudry MD (2016) Immunotoxicity of commercial-mixed glyphosate in broad snouted caiman (Caiman latirostris). Chem-Biol Interact 244:64-70. https://doi.org/10.1016/j.cbi.2015.11.031

van der Sluijs JP, Amaral-Rogers V, Belzunces LP, Van Lexmond MB, Bonmatin JM, Chagnon M, Downs CA, Furlan L, Gibbons DW, Giorio C, Girolami V, Goulson D, Kreutzweiser DP, Krupke C, Liess M, Long E, McField M, Mineau P, Mitchell EAD, Morrissey CA, Noome DA, Pisa L, Settele J, Simon-Delso N, Stark JD, Tapparo A, Van Dyck H, van Praagh J, Whitehorn PR, Wiemers M (2015) Conclusions of the Worldwide Integrated Assessment on the risks of neonicotinoids and fipronil to 
biodiversity and ecosystem functioning. Environ Sci Pollut Res 22:148-154. https://doi.org/10.1007/s11356-014-3229-5

Stahlschmidt P, Brühl CA (2012) Bats at risk? Bat activity and insecticide residue analysis of food items in an apple orchard. Environ Toxicol Chem 31(7):1556-1563. https://doi.org/10.1002/etc.1834

Stanley DA, Russell AL, Morrison SJ, Rogers C, Raine N (2016) Investigating the impacts of field-realistic exposure to a neonicotinoid pesticide on bumblebee foraging, homing ability and colony growth. J Appl Ecol 53:1440-1449. https://doi.org/10. 1111/1365-2664.12689

Stebbings RE, \& Griffith F (1986) Distribution and status of bats in Europe. Abbots Ripton, Huntingdon, Institute of Terrestrial Ecology, $142 \mathrm{pp}$

Stenoien C, Nail KR, Zalucki JM, Parry H, Oberhauser KS, Zalucki MP (2018) Monarchs in decline: a collateral landscape level effect of modern agriculture. Insect Sci 25:528-541. https://doi. org/10.1111/1744-7917.12404

Streloke M (2011) Risk assessment and management of herbicides: obligations of the new EU regulations. J für Verbraucherschutz und Lebensmittelsicherheit 6(1):55-59. https://doi.org/10.1007/ s00003-011-0684-5

van Swaay C, Cuttelod A, Collins S, Maes D, Munguira ML, Šašić M, Settele J, Verovnik R, Verstrael T, Warren M, Wiemers M, Wynhof I (2010) European Red List of butterfies. Publications Office of the European Union, Luxembourg

van Swaay C, Collins S, Dušej G, Maes D, Munguira ML, Rakosy L, Ryrholm N, Šašić M, Settele J, Thomas JA, Verovnik R, Verstrael T, Warren M, Wiemers M, Wynhoff I (2012) Dos and Don'ts for butterflies of the Habitats Directive of the European Union. Nat Conserv 1:73-153. https://doi.org/10.3897/na tureconservation.1.2786

Tarazona JV, Court-Marques D, Tiramani M, Reich H, Pfeil R, Istace F, Crivellente F (2017) Glyphosate toxicity and carcinogenicity: a review of the scientific basis of the European Union assessment and its differences with IARC. Arch Toxicol 91:2723-2743. https://doi.org/10.1007/s00204-017-1962-5

Thogmartin WE, Wiederholt R, Oberhauser K, Drum RG, Diffendorfer JE, Altizer S, Taylor OR, Pleasants J, Semmens D, Semmens B, Erickson R, Libby K, Lopez-Hoffman L (2017) Monarch butterfly population decline in North America: identifying the threatening processes. R Soc Open Sci 4(9):170760. https://doi. org/10.1098/rsos. 170760

Thomas P, Holland N, Bolognesi C, Kirsch-Volders M, Bonassi S, Zeiger E, Knasmuelle S, Fenech M (2009) Buccal micronucleus cytome assay. Nat Protoc 4(6):825. https://doi.org/10.1038/nprot. 2009.53

Thompson HM (2003) Behavioural effects of pesticides in bees-their potential for use in risk assessment. Ecotoxicology 12:317-330. https://doi.org/10.1023/A:1022575315413

Uren Webster TM, Laing LV, Florance H, Santos EM (2014) Effects of glyphosate and its formulation, roundup, on reproduction in zebrafish (Danio rerio). Environ Sci Technol 48(2):1271-1279. https://doi.org/10.1021/es404258h

Vázquez DE, Ilina N, Pagano EA, Zavala JA, Farina WM (2018) Glyphosate affects the larval development of honey bees depending on the susceptibility of colonies. PLoS ONE 13(10): e0205074. https://doi.org/10.1371/journal.pone.0205074

Wagner N, Mingo V, Schulte U, Lötters S (2015) Risk evaluation of pesticide use to protected European reptile species. Biol Conserv 191:667-673. https://doi.org/10.1016/j.biocon.2015.08.002

Wagner N, Rödder D, Brühl CA, Veith M, Lenhardt PP, Lötters S (2014) Evaluating the risk of pesticide exposure for amphibian species listed in Annex II of the European Union Habitats Directive. Biol Conserv 176:64-70. https://doi.org/10.1016/j. biocon.2014.05.014

Woźniak E, Sicińska P, Michałowicz J, Woźniak K, Reszka E, Huras B, Zakrzewski J, Bukowska B (2018) The mechanism of DNA damage induced by Roundup 360 PLUS, glyphosate and AMPA in human peripheral blood mononuclear cells-genotoxic risk assessment Food Chem Toxicol 120:510-522. https://doi.org/10. 1016/j.fct.2018.07.035

Xu Y, Jing LiA, Li K, Qin J, Li H (2017) Effects of glyphosate-based herbicides on survival, development and growth of invasive snail (Pomacea Canaliculata). Aquat Toxicol 193:136-143. https://doi. org/10.1016/j.aquatox.2017.10.011

Ye CJ, Sharpe Z, Alemara S, Mackenzie S, Liu G, Abdallah B, Horne S, Regan S, Heng HH (2019) Micronuclei and genome chaos: changing the system inheritance. Genes 10(5):366. https://doi. org/10.3390/genes10050366

Zhang L, Rana I, Shaffer RM, Taioli E, Sheppard L (2019) Exposure to glyphosate-based herbicides and risk for non-Hodgkin lymphoma: a meta-analysis and supporting evidence. Mutat Res Rev Mutat Res 781:186-206. https://doi.org/10.1016/j.mrrev.2019.02. 001

Zhang ZY, Li Z, Huang Q, Zhang XW, Ke L, Yan WY, Zhang LZ, Zeng ZJ (2020) Deltamethrin impairs honeybees (Apis mellifera) dancing communication. Arch Environ Contam Toxicol 78:117-123. https://doi.org/10.1007/s00244-019-00680-3 